\title{
Wisata Kuliner di Sentra Primer Barat Jakarta
}

\author{
Cindy Putri ${ }^{1}$ dan Andi Surya Kurnia ${ }^{2}$ \\ ${ }^{1}$ Jurusan Arsitektur Fakultas Teknik, Universitas Tarumanagara Jakarta \\ Email: thr.cindyputri@gmail.com \\ ${ }^{2}$ Jurusan Arsitektur Fakultas Teknik, Universitas Tarumanagara Jakarta \\ Email: andik@ft.untar.ac.id
}

\begin{abstract}
ABSTRAK
Kawasan Sentra Primer Barat yang sedang berkembang pesat memiliki suatu fenomena keseharian masyarakat yaitu pasar kaget yang dikenal dengan pasar kaget CNI, karena lokasinya yang berada di depan kantor perusahaan multilevel marketing (MLM) CNI. Pedagang kaki lima (PKL) yang terakumulasi di pasar kaget seringkali dianggap membebani kota, padahal memiliki manfaat sosial-ekonomi. Secara ekonomi, PKL menjadi katup pengaman krisis ekonomi dan pemenuhan kebutuhan bagi masyarakat berpenghasilan rendah. Jika dilihat dari segi sosial, PKL menjadi rekreasi masyarakat berpenghasilan rendah. Rekreasi diperlukan karena merupakan hak manusia terlepas dari pelaku dan caranya. Penelitian ini bertujuan untuk membuka pemikiran tentang sarana rekreasi sosial yang merangkul masyarakat berpenghasilan rendah tanpa mengabaikan konteks kawasannya. Metode penelitian yang digunakan yaitu metode penelitian lapangan berupa metode survai dan deskriptif serta metode penelitian bukan lapangan yaitu metode penelitian kepustakaan. Kesimpulan hasil penelitian yaitu diperlukannya sarana rekreasi kuliner berbasis PKL didukung program aktivitas rekreasi anak-anak, pusat perbelanjaan dengan harga terjangkau, dan ruang publik untuk memenuhi kebutuhan masyarakat berpenghasilan rendah dan menjembatani kelas-kelas sosial di Sentra Primer Barat.
\end{abstract}

Kata kunci: Arsitektur, Rekreasi, Sosial Humanisme, Wisata Kuliner.

\section{PENDAHULUAN}

Perkembangan DKI Jakarta memiliki arah dan karakteristik yang berbeda pada kelima kotamadya yang ada sesuai dengan Rencana Tata Ruang Wilayah 2030. Salah satu rencana pembangunan yang sedang melaju cepat yaitu pembangunan Sentra Primer Barat di kotamadya Jakarta Barat ("Kawasan Sentra Primer Barat Baru Terus Menggeliat”, www.beritajakarta.com). Dibalik seluruh rencana pengembangan Sentra Primer Barat dan melambungnya nilai dan prestis sosial-ekonomi kawasan tersebut, terdapat fenomena keseharian masyarakat yaitu pasar kaget berisi pedagang kaki lima (PKL) yang berlangsung setiap hari di sepanjang jalan sebuah blok bangunan Sentra Primer Barat.

Pedagang kaki lima (PKL) seringkali dipandang sebagai beban perkotaan, padahal memberikan manfaat secara ekonomi dan sosial. Manfaat PKL dari segi ekonomi antara lain katup pengaman saat krisis ekonomi dan penyedia barang kebutuhan masyarakat berpenghasilan rendah (BAPPENAS, 2009:33). Dari segi sosial, PKL yang terakumulasi di pasar-pasar kaget menjadi rekreasi masyarakat berpenghasilan rendah. Kecenderungan rekreasi masyarakat dipengaruhi oleh stratifikasi dan diferensiasi sosial, sehingga masyarakat berpenghasilan rendah cenderung mencari hiburan lokal yang murah (Waluya, 2007:25).

Rekreasi menjadi penting karena manusia membutuhkan rekreasi untuk menyegarkan diri dari kepenatan (Budhi Santosa, 2001:42), namun masyarakat kelas bawah di ibukota dengan daya beli rendah sudah tidak mampu lagi menikmati sarana rekreasi yang sedang tren seperti mall ("Di balik megahnya mal-mal Jakarta yang ber-AC", www.theguardian.com). PKL dan pasar kaget tidak dapat memiliki ruang di kota karena statusnya yang ilegal.

Upaya penataan dan pemberdayaan PKL telah dilakukan oleh pemerintah, tetapi berujung pada penggusuran tanpa relokasi yang jelas sehingga isu PKL liar tidak pernah selesai ("PKL di Kawasan CNI Kembangan akan Ditata", www.beritajakarta.com). Dalam kasus Sentra Primer 
Barat, penggusuran PKL telah dilakukan dan direncanakan penataannya, tetapi sampai saat ini pasar kaget masih mengisi jalan di Sentra Primer Barat, tepatnya di depan kantor CNI.

Dalam Universal Declaration of Human Rights pasal 24, tertulis bahwa rekreasi merupakan hak manusia ("Universal Declaration of Human Rights”, ohchr.org); terlepas dari pelakunya dan cara melakukannya. Maka dari sudut pandang sosial humanisme, dibutuhkan sarana rekreasi terintegrasi lokasi binaan bagi masyarakat sebagai bentuk intervensi arsitektur agar dapat menjembatani perbedaan kelas sosial-ekonomi di Sentra Primer Barat dan mewujudkan hak bagi setiap manusia didalamnya untuk melakukan rekreasi sesuai keinginan dan kemampuannya.

\section{Rumusan masalah:}

a. Apa esensi dari kegiatan dan interaksi yang terjadi pada PKL dalam pasar kaget CNI?

b. Apa konteks sosial humanisme yang terjadi di kawasan Sentra Primer Barat?

c. Bagaimana menghubungkan esensi kegiatan dan interaksi PKL dalam pasar kaget CNI guna mengoptimalkan konteks sosial humanism sebagai sarana rekreasi Sentra Primer Barat?

\section{Tujuan penelitian}

Memberikan sumbangan pemikiran secara arsitektural kepada Pemerintah Provinsi DKI Jakarta dan pihak-pihak yang bersangkutan dari sudut pandang sosial humanisme berupa sarana rekreasi terintegrasi dengan program Pemerintah Provinsi DKI Jakarta terkait penataan dan pemberdayaan PKL. Sarana rekreasi yang dimaksud yaitu bagi masyarakat kota berpenghasilan rendah dengan tidak mengabaikan kepentingan dan konteks lokasinya.

\section{Manfaat penelitian}

Terciptanya sarana rekreasi yang humanis antar kelas sosial di Sentra Primer Barat, yang berhubungan juga dengan pemenuhan kebutuhan ekonomi, sehingga memperbaiki kehidupan masyarakat berpenghasilan rendah dari segi sosial ekonomi, serta mengembalikan titik berjualan PKL ke fungsi yang seharusnya demi menjaga ketertiban umum.

\section{METODE PENELITIAN}

Metode penelitian yang digunakan untuk topik yang digunakan adalah metode penelitian lapangan yaitu metode survai dan metode deskriptif dan bukan metode penelitian bukan lapangan yaitu metode penelitian kepustakaan. Kedua metode ini berdasarkan buku Metode Penulisan Ilmiah oleh E. Zaenal Arifin.

\section{Tahap pengumpulan data}

Data diperoleh melalui wawancara dengan pihak yang terlibat yaitu PKL dan pengunjung guna memperoleh paparan langsung dari pengguna di lokasi pengamatan. Observasi di lapangan untuk memperoleh data teknis PKL (jumlah dan jenis), foto, dan deskripsi tertulis tentang kondisi lokasi pengamatan. Kemudian melalui pencarian informasi yaitu data-data tertulis seperti artikel, statistik, perundangan, literatur, yang berasal dari media cetak berupa buku dan media digital berupa internet.

\section{Tahap Pengorganisasian}

Data awal yang diperoleh dari tahap pengumpulan data kemudian diseleksi dan digolongkan berdasarkan jenisnya. Data yang diperoleh dari penelitian bersifat kuantitatif (angka) yang diolah ke dalam bentuk diagram pie dan kualitatif (deskripsi) yang diolah dalam bentuk tabel dan narasi. 


\section{Tahap Pemeriksaan}

Kegiatan pemeriksaan terhadap data awal yang diperoleh untuk memastikan kebenaran data agar dapat dipertanggungjawabkan. Data kemudian dipilah sehingga data yang terpilih memang berdayaguna untuk perancangan dan tidak berulang. Setelah itu dilakukan penyuntingan bahasa dan meringkas penjelasan agar lebih padat informasi.

\section{Tahap Penyajian}

Kegiatan pengetikan naskah dengan memerhatikan tata letak unsur dalam penelitian pada keseluruhan naskah penelitian. Dalam hal ini adalah pengecekan EYD dan kata-kata baku serta ketelitian penulisan.

\section{HASIL DAN PEMBAHASAN}

\section{Interaksi sosial sebagai dasar proses sosial}

Proses-proses sosial adalah cara-cara berhubungan yang dapat dilihat apabila para individu dan kelompok-kelompok saling bertemu dan menentukan sistem serta bentuk hubungan tersebut atau apa yang akan terjadi apabila ada perubahan-perubahan yang menyebabkan goyahnya cara-cara hidup yang telah ada. Dapat diartikan yaitu pengaruh timbal balik sebagai akibat hubungan timbal balik antara individu dengan kelompok dan kelompok dengan kelompok lain mengenai berbagai aspek kehidupan (politik, ekonomi, sosial, budaya, dan keamanan). (Soekanto dalam Umam, 2014:17).

Interaksi sosial adalah kunci rotasi kehidupan sosial karena tanpa interaksi sosial, maka tidak ada kehidupan bersama. Bertemunya orang-perorangan secara fisik saja tidak akan menghasilkan pergaulan hidup dalam kelompok sosial. Interaksi sosial hanya berlangsung antara pihak-pihak apabila terjadi reaksi dari keduanya (Soekanto dalam Umam, 2014:19).

\section{Syarat-syarat interaksi sosial}

Interaksi sosial tidak akan terjadi tanpa adanya kontak sosial dan komunikasi. Berikut ini adalah penjabaran kontak sosial dan komunikasi secara ringkas (Soekanto dalam Umam, 2014:23-25).

a. Kontak Sosial

Sebagai gejala sosial, kontak tidak perlu secara fisik karena adanya perkembangan teknologi dimana kontak sosial dapat terjadi melalui alat-alat komunikasi (telepon, telegram, dan lainnya).

b. Komunikasi

Hal terpenting dalam komunikasi yaitu adanya kegiatan saling menafsirkan perilaku (pembicaraan, gerakan-gerakan fisik, atau sikap) dan perasaan-perasaan yang disampaikan.

\section{Pengertian rekreasi dan hak untuk rekreasi}

Rekreasi adalah penyegaran kembali badan dan pikiran; sesuatu yang menggembirakan hati dan menyegarkan seperti hiburan, piknik. Berekreasi adalah untuk mencari hiburan; bermain-main santai; bersenang-senang (kbbi.web.id). Setiap orang berhak atas istirahat dan liburan, termasuk pembatasan-pembatasan jam kerja yang layak dan hari libur berkala, dengan menerima upah. ("the Universal Declaration of Human Rights", pasal 24, ohchr.org).

Menurut Budhi Santosa (2001:42) menghibur diri (rekreasi) pada dasarnya adalah aktivitas manusia untuk memperoleh kesenangan serta kebahagiaan lewat kenikmatan fisik maupun rohani. Rasa senang dan bahagia tersebut diperlukan sebagai obat terhadap kelelahan, kedukaan, dan kesepian yang dialami.

\section{Klasifikasi kegiatan rekreasi}

Gold (1980:114) menjabarkan kategori pengalaman rekreasi menjadi empat kategori utama: 
a. Physical (fisik) yaitu rekreasi yang membutuhkan tenaga untuk menikmatinya.

b. Social (sosial) yaitu rekreasi dengan mayoritas interaksi sosial sebagai pengalaman rekreasi utama.

c. Cognitive (kognitif) yaitu rekreasi yang bersifat kebudayaan, edukasi, kreatif, dan kegiatan estetis.

d. Environment related recreation (rekreasi yang berhubungan dengan lingkungan) yaitu rekreasi yang membutuhkan sumber daya alam seperti air, pohon, hewan liar, dan unsur lainnya untuk latar dan aktivitas.

Rekreasi dapat bersifat aktif yaitu kegiatan yang mengharuskan individual pelaku untuk berpartisipasi langsung, contohnya berdansa. Sebaliknya, rekreasi bersifat pasif hanya memerlukan pihak pelaku untuk menjadi pengamat atau penonton contohnya mendengarkan konser musik. (“What are different types of recreation?", reference.com).

Gold (1980:117) juga memaparkan klasifikasi kegiatan rekreasi dari pengalaman rekreasi fisik dan sosial, dimana rekreasi fisik dapat dilakukan di luar atau dalam ruangan dan berhubungan dengan kegiatan olahraga. Sedangkan rekreasi sosial dapat dilihat di tabel 1.

Tabel 1. Klasifikasi kegiatan rekreasi sosial

\begin{tabular}{|c|c|c|}
\hline Pengalaman Rekreasi & Kelompok Kegiatan & Contoh Kegiatan \\
\hline \multicolumn{3}{|l|}{ Rekreasi sosial } \\
\hline \multirow[b]{2}{*}{ Luar ruangan (outdoor) } & Partisipan & $\begin{array}{l}\text { Piknik, menari, berbelanja di } \\
\text { pasar loak, mengunjungi } \\
\text { pameran, pergi ke restoran }\end{array}$ \\
\hline & Penonton & $\begin{array}{l}\text { Menonton pertandingan } \\
\text { olahraga, menonton } \\
\text { pertunjukkan, } \\
\text { mendengarkan lagu }\end{array}$ \\
\hline \multirow[t]{2}{*}{ Dalam ruangan (indoor) } & Partisipan & $\begin{array}{l}\text { Pertemuan, membuat } \\
\text { prakarya, mengunjungi } \\
\text { bazaar, menari, permainan } \\
\text { meja }\end{array}$ \\
\hline & Penonton & $\begin{array}{l}\text { Menonton pertandingan } \\
\text { olahraga, menonton film, } \\
\text { menonton televisi }\end{array}$ \\
\hline
\end{tabular}

\section{Hubungan diferensiasi sosial dan stratifikasi sosial dengan rekreasi}

Diferensiasi sosial menurut Waluya (2007:5-16) adalah penggelompokan masyarakat ke dalam kelas-kelas secara horizontal, seperti ras, etnis, klan, agama, profesi, dan jenis kelamin. Stratifikasi sosial adalah perbedaan masyarakat ke dalam kelas secara bertingkat (hierarkis). Kriterianya dibagi berdasarkan kekayaan, kekuasaan, kehormatan, dan ilmu pengetahuan (Waluya, 2007:16-20). Adanya fenomena diferensiasi dan stratifikasi sosial dalam kehidupan masyarakat tentu akan menimbulkan konsekuensi tersendiri.

Waluya (2007:24) menjelaskan dalam tindakan dan interaksi sosial, stratifikasi sosial memiliki dua unsur pokok, yaitu status dan peran. Di dalam masyarakat, dengan adanya perbedaan status dan peran sosial akan timbul perbedaan perilaku yang terlihat dalam gaya hidup. Salah satunya adalah dalam cara berekreasi. Masyarakat kelas atas akan cenderung untuk berekreasi ke luar negeri, kelas menengah berekreasi ke daerah tujuan wisata dalam negeri, dan masyarakat kelas bawah berekreasi ke lokasi hiburan lokal di daerahnya sendiri (Waluya, 2007:25). 
Pada masyarakat kelas bawah banyak yang menyukai hiburan dari kesenian daerah masingmasing. Karakter kesenian tradisional sangatlah demokratis karena dapat ditonton tanpa keseriusan macam teater modern atau musik klasik. Lebih lagi bila tontonan tersebut gratis; semacam film layar tancap.

\section{Ruang publik sebagai wadah rekreasi}

Ruang publik menurut Carr dalam Purnamasari (2012) adalah ruang atau lahan umum tempat masyarakat dapat melakukan kegiatan publik fungsional maupun kegiatan sampingan lainnya yang dapat mengikat suatu komunitas, baik itu kegiatan sehari-hari ataupun berkala.

Carr juga menuliskan tipologi ruang terbuka publik dalam perkembangannya memiliki variasi tipe dan karakter antara lain taman publik, lapangan, plaza, pasar, jalan, lapangan bermain, ruang terbuka untuk masyarakat, jalur hijau, atrium, dan tepi laut.

Peran ruang publik dalam kehidupan kota yang serba cepat adalah agar kehidupan kota berjalan secara sehat dengan warga yang bahagia. Ruang publik dapat menghadirkan kebahagiaan sosial dari interaksi terhadap sesama dan munculnya sikap saling menghargai identitas masing-masing. Hal ini membawa dampak positif bagi keberlangsungan pergaulan sosial yang heterogen di kota ("Ruang Publik Perkotaan dan Creative Governance Membangun Harapan", www.kompasiana.com).

\section{Pedagang kaki lima (PKL) dan tindakan pemerintah}

Pedagang Kaki Lima, yang selanjutnya disingkat PKL, adalah pelaku usaha yang melakukan usaha perdagangan dengan menggunakan sarana usaha bergerak maupun tidak bergerak, menggunakan prasarana kota, fasilitas sosial, fasilitas umum, lahan dan bangunan milik pemerintah dan/atau swasta yang bersifat sementara/tidak menetap (Peraturan Menteri dalam Negeri Nomor 41 Tahun 2012 Pasal 1).

Pedagang Kaki Lima (PKL) tidak hanya dibiarkan oleh pemerintah. Dalam Peraturan Menteri Dalam Negeri Republik Indonesia Nomor 41 Tahun 2012 tentang Pedoman Penataan dan Pemberdayaan Pedagang Kaki Lima Pasal 1, penataan PKL adalah upaya yang dilakukan oleh pemerintah daerah dengan penetapan lokasi binaan untuk menertibkan lokasi PKL demi kepentingan umum dan aspek lainnya. Dalam hal ini, lokasi binaan adalah lokasi yang telah ditetapkan peruntukannya bagi PKL yang diatur oleh pemerintah daerah, baik bersifat permanen maupun sementara. Lokasi binaan yang dimaksud dapat bersifat permanen atau sementara (Pasal 34 ayat 1$)$.

Sedangkan tindakan pemberdayaan PKL adalah upaya yang dilakukan oleh pemerintah, pemerintah daerah, dunia usaha dan masyarakat secara sinergis untuk menumbuhkan iklim ekonomi yang baik bagi PKL agar usahanya berkembang (Pasal 1).

\section{Hasil observasi lapangan}

Pada gambar 1 titik yang ditandai kotak merah merupakan kawasan Sentra Primer Barat, yaitu tepat di depan Kantor CNI di mana sudah dikenal dengan kekumuhan pasar kaget yang diisi oleh tenda dan gerobak PKL. Penyebab utama hal ini terjadi adalah jalanan yang sepi di CNI akibat belum adanya proyek yang dibangun disekitarnya dan lokasi yang strategis dan dikelilingi perkantoran, pusat perbelanjaan, dan kegiatan lain yang memiliki potensi konsumen yaitu pegawai/karyawan. 
Kelak tanah-tanah kosong ini akan dibangun proyek Sentra Primer Barat menyebabkan pasar malam dan PKL yang berjualan secara ilegal ini akan tergusur. Berdasarkan hasil survey lapangan, jenis sarana usaha terdiri dari 133 gerobak PKL, 37 gelaran, 206 tenda, dan 1 sepeda motor disajikan dalam diagram 1.

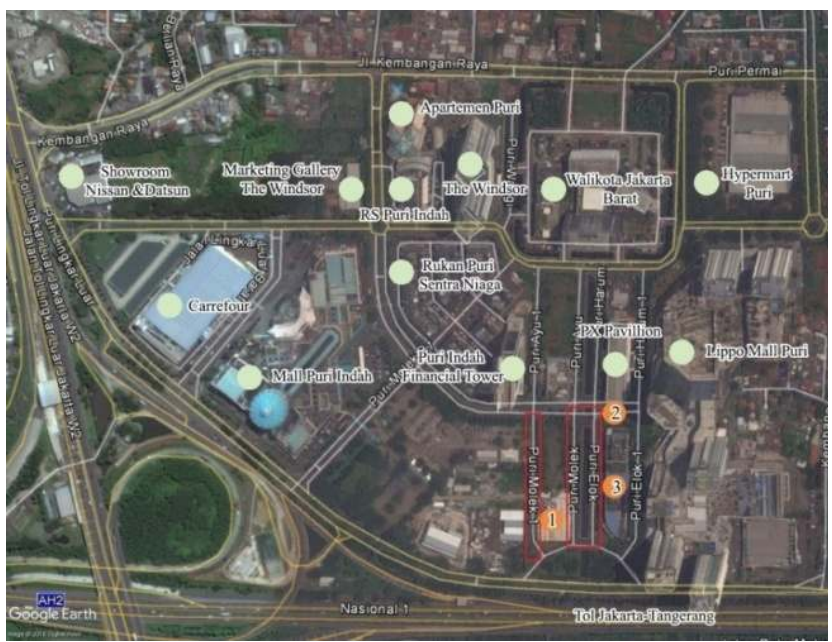

Gambar 1. Lokasi pengamatan (Sumber: Google Earth, 2017)

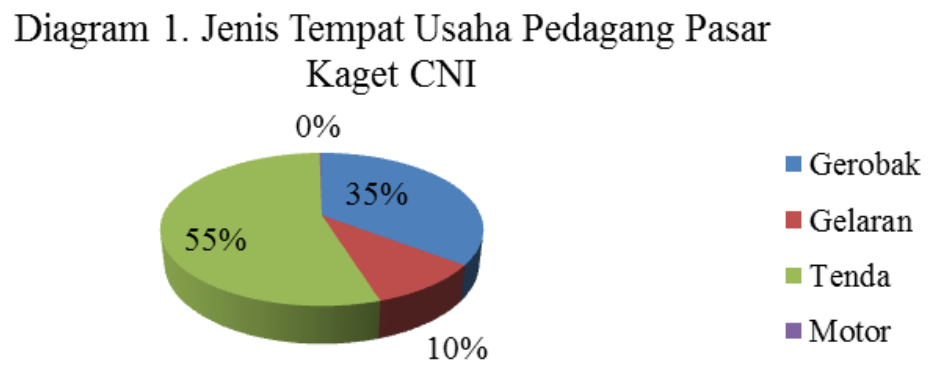

Barang-barang yang diperdagangkan yaitu $62 \%$ pangan berupa jajanan dan $38 \%$ non-pangan. Data dan persenan terperinci dari non-pangan dapat dilihat pada diagram 2.

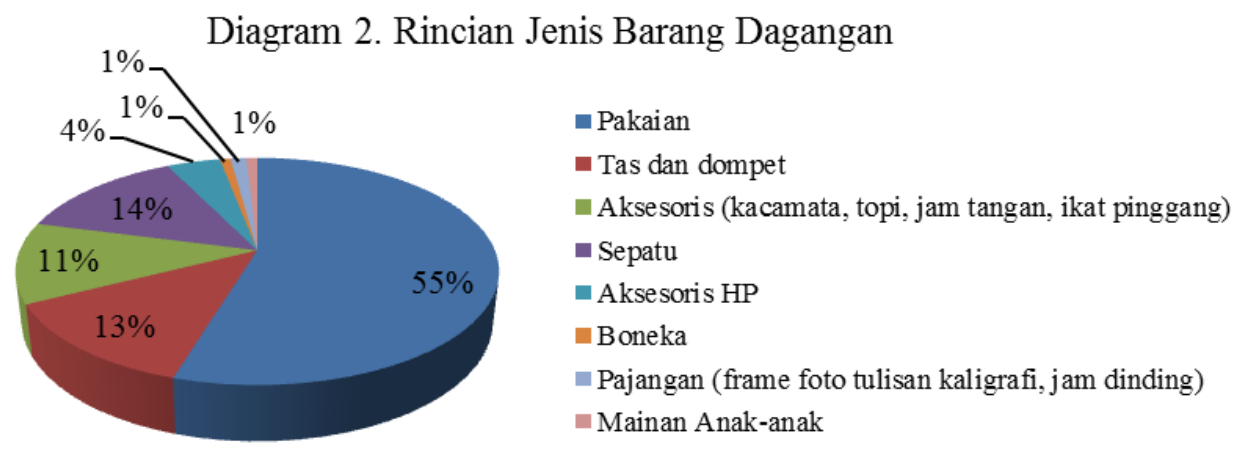

Diagram 3 menunjukkan persentase dan kelompok usia pengunjung di pasar kaget CNI. Sebagian besar pengunjung merupakan kelompok usia dewasa awal. Diikuti dengan remaja akhir, anak-anak, dan seterusnya. 
Berdasarkan hasil survey kegiatan di pasar malam CNI, di siang hari kondisi sepi dan hanya beberapa tenda saja yang beroperasi. Menjelang sore pukul 17.30, pedagang sudah mulai mempersiapkan gelaran, tenda, dan gerobak miliknya untuk berdagang, lalu puncak keramaian berlangsung pada pukul 19.30. Hal menarik adalah adanya delman dan permainan kereta mesin anak-anak di beberapa titik dan juga berkeliling dengan mobil. Foto observasi dalam tiga waktu dapati dapat dilihat di tabel 2 .

\section{Diagram 3. Rala-rala Kalegori Usia Pengunjung Pasar Kagel CNI}

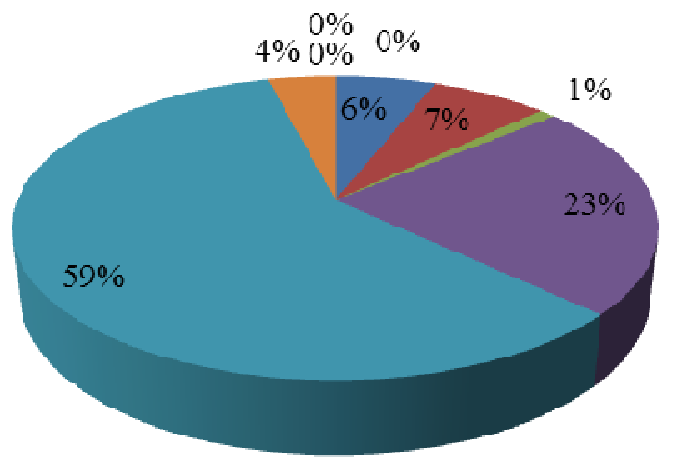

$$
\begin{aligned}
& \text { Balita (0-5) } \\
& \text { Anak-anak (6-11) } \\
& \text { Remaja Awal (12-16) } \\
& \text { Remaja Akhir (17-25) } \\
& \text { Dewasa awal (26-35) } \\
& \text { Dewasa akhir (36-15) } \\
& \text { Lansia awal (46-55) } \\
& \text { Lansia akhir (56-65) } \\
& \text { Manula >66 tahun }
\end{aligned}
$$

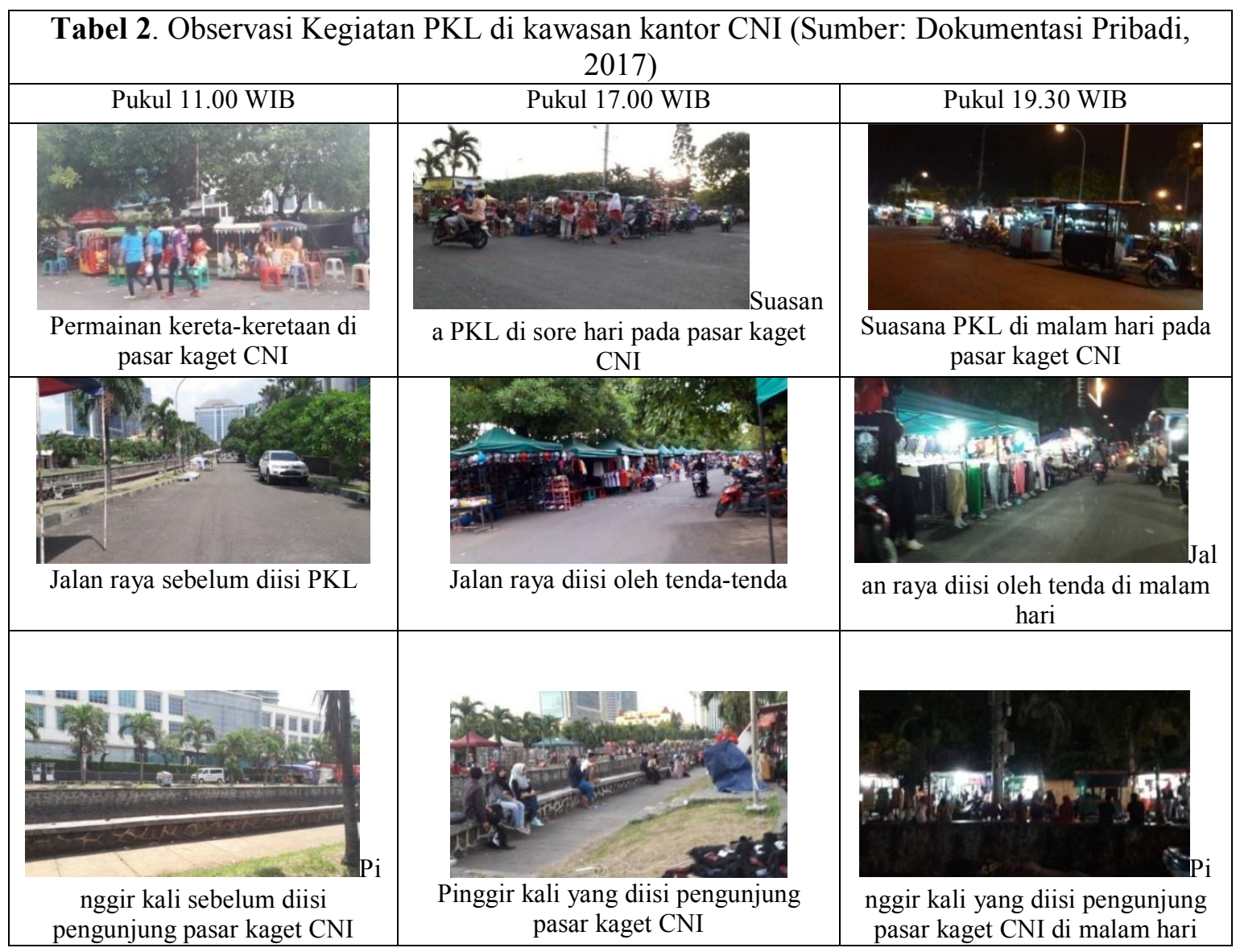




\section{Esensi rekreasi yang tersirat pada pasar kaget CNI}

Keberadaan pasar kaget CNI menjadi sebuah sarana rekreasi yang terjangkau bagi masyarakat berpenghasilan rendah di sekitar kawasan Sentra Primer Barat (Kembangan, Jakarta Barat). Hal ini dapat dikaitkan dengan teori Waluya (2007:25) bahwa masyarakat kelas bawah cenderung mencari hiburan lokal.

Rekreasi yang diperoleh itu sendiri berupa rekreasi sosial baik partisipan maupun penonton yang dilakukan di luar ruangan berdasarkan teori klasifikasi kegiatan rekreasi oleh Gold (1980:117). Pengunjung datang tanpa perlu mengeluarkan uang dalam jumlah besar dan rekreasi diperoleh dengan melihat-lihat (window shopping), makan sambil mengobrol santai, dan mendengarkan lagu yang sesekali diputar dari tenda-tenda. Kesimpulannya, pengunjung melakukan rekreasi dengan berbincang dan jajan dengan teman/keluarga tanpa wujud fisik rekreasi yang umum diketahui masyarakat seperti taman bermain.

\section{Dinamika kelas-kelas sosial di Sentra Primer Barat}

Sentra Primer Barat adalah kawasan pusat kegiatan primer dan dikelilingi oleh perumahan masyarakat golongan atas. Fenomena pasar kaget di tengah Sentra Primer Barat ini menunjukkan adanya stratifikasi sosial yang jelas terlihat antara golongan atas, menengah dan bawah sehingga salah satunya terancam tergeser. Menyatukan berbagai kelas sosial sepertinya mustahil, namun dengan mencari kebutuhan yang kontekstual pada kawasan dan benang merah yang dapat menyatukannya, maka interaksi sosial antar kelas sosial ini dapat dijembatani dengan positif tanpa mengabaikan salah satunya.

\section{PKL sebagai benang merah kegiatan rekreasi dalam konteks sosial humanisme di Sentra Primer Barat}

Kebutuhan pegawai/karyawan di Sentra Primer Barat sebagai kelas menengah bawah yaitu sarana rekreasi dan pemenuhan kebutuhan pangan menjadi penggerak ekonomi pasar kaget CNI. Sedangkan bagi masyarakat berpenghasilan rendah, pasar kaget CNI menjadi sarana rekreasi dan pemenuhan kebutuhan sehari-harinya dengan harga yang terjangkau, atau rekreasi hanya dengan duduk santai mengisi waktu karena keterbatasan biaya untuk membeli barang-barang. Di sini PKL berperan sebagai benang merah yang menyatukan kelas-kelas sosial tersebut. Rekomendasi dari sisi arsitektural adalah dengan mewadahi kegiatan rekreasi sosial dan pemenuhan kebutuhan dengan mengeksplorasi lebih lanjut atas peran PKL ini.

\section{KESIMPULAN}

Pasar kaget CNI, di Sentra Primer Barat terjadi karena adanya kebutuhan masyarakat berpenghasilan rendah untuk rekreasi dan memenuhi kebutuhannya. Esensi rekreasi yang muncul dari pasar kaget CNI adalah rekreasi sosial di luar ruangan secara partisipan dan penonton oleh pengunjungnya.

Keberadaan pegawai/ karyawan di sekitar Sentra Primer Barat menjadi penggerak ekonomi pasar kaget ini sehingga tidak mudah untuk dihilangkan. Dengan adanya rencana pengembangan kedepannya, keberadaan pasar kaget di CNI terancam dan akan berdampak besar pada sosialekonomi para pelaku di dalamnya. Namun, kondisinya yang mengisi ruang jalan adalah melanggar hukum sehingga tidak dapat dipertahankan dengan alas an apapun di lokasi saat ini.

Upaya penataan dalam bentuk intervensi sosial-humanisme dengan menciptakan sarana rekreasi kuliner berbasis pedagang kaki lima karena tingginya peminatan pada kuliner. Rekreasi kuliner sebagai program utama didukung dengan program aktivitas rekreasi untuk anak, tempat 
perbelanjaan dengan harga terjangkau, dan ruang publik terbuka untuk menjawab kebutuhan yang dicari di pasar kaget saat ini dan menjembatani kelas-kelas sosial di Sentra Primer Barat.

Pedagang kaki lima kuliner ini dapat diolah dari segi bentuk kios, metode aktivitas (cara makanminum, cara duduk, dan jenis barang dagangan) agar dapat menarik target pasar golongan menengah di Sentra Primer Barat. Hal ini dilakukan agar program dapat berjalan karena adanya penggerak komersil yaitu para pegawai di Sentra Primer Barat sebagai potensi konsumen selain masyarakat berpenghasilan rendah di Kembangan.

\section{REFERENSI}

Arifin, E. Zaenal. 2013. Metode Penulisan Ilmiah. Tangerang: Pustaka Mandiri.

Budhi Santosa, Iman. 2001. Kisah Polah Tingkah. Yogyakarta: LKiS Yogyakarta.

Gold, Seymour B. 1980. Recreation Planning and Design. Amerika: Mc.Graw Hill. Inc.

Kedeputian Evaluasi Kinerja Pembangunan. 2009. Kajian Evaluasi Pembangunan Sektoral: Peran Sektor Informal Sebagai Katup Pengaman Masalah Ketenagakerjaan. Jakarta: BAPPENAS.

Peraturan Menteri dalam Negeri Nomor 41 Tahun 2012 tentang Pedoman Penataan dan Pemberdayaan Pedagang Kaki Lima.

Purnamasari, et.al. 2012. Kajian Spasial Ruang Publik (Public Space) Perkotaan untuk Aktivitas Demonstrasi Mahasiswa di Kota Makassar. Jurnal Bumi Indonesia. Vol.1, no.2: 27-36.

Umam, Choirul. 2014. Proses-proses Sosial dan Interaksi Sosial. Bahan ajar. Depok: Program S1 Ilmu Komunikasi.

Waluya, Bagja. 2007. Sosiologi: Menyelami Fenomena Sosial di Masyarakat. Bandung: PT Setia Purna Inves.

www.beritajakarta.com/read/39726/PKL_di_Kawasan_CNI_Kembangan_akan_Ditata\#.WHD7c 1N97IV (diakses 27 Desember 2016 pukul 15.19)

www.beritajakarta.com/read/4334/Kawasan_Sentra_Primer_Barat_Baru_Terus_Menggeliat (diakses 20 Februari 2017 pukul 15.49)

www.kompasiana.com/fitrawanumar/ruang-publik-perkotaan-dan-creative-governancemembangun-harapan_56096dc85497736d0ad73885 (diakses 22 September 2016 pukul 17.31)

www.ohchr.org/en/udhr/pages/language.aspx?langid=inz (diakses 16 Februari 2017 pukul 22.21) www.theguardian.com/cities/2016/nov/24/di-dalam-realitas-alternatif-megamall-jakarta-yangberpendingin-udara diakses (30 Januari 2017 pukul 13.50) 